\title{
Size of the Company as the Main Determinant of Talent Management in Slovakia
}

\author{
Radovan Savov *, Drahoslav Lančarič (D) and Jana Kozáková
}

Faculty of Economics and Management, Slovak University of Agriculture in Nitra, Tr. A. Hlinku 2, 94976 Nitra, Slovakia; drahoslav.lancaric@uniag.sk (D.L.); jana.kozakova@uniag.sk (J.K.)

* Correspondence: radovan.savov@uniag.sk

Received: 3 February 2020; Accepted: 28 February 2020; Published: 6 March 2020

\begin{abstract}
Nowadays, all sources in the reproduction process are easily substituted, thus the most important factors in reaching a competitive advantage are human resources. Talent management is the process oriented to enrich higher the ability of employers to increase their quality and productivity. Globalization has changed the structure of the companies in Slovakia, depending on the size of the company. This paper compares how the size of the company influences the main phases of the talent management process (strategy, identification, assessment, development, retaining). A scaled questionnaire was applied as a tool for data collection in 381 companies operating business in Slovakia. Questionnaire reliability was verified by Cronbach's alpha. To verify the existence of statistically significant differences between individual groups of respondents, ANOVA was used. We found that the main differences between small and large companies were identified in the phases of talent identification and talent development. In bigger companies, management is more focused on HR plans that include talent identification and acquisition and have more possibilities to develop talented individuals. On the other side we could see that small companies were more successful in the process of retaining the talents. Talented people in small companies are more loyal to the employers and stay in the company for longer periods than talented individuals in large companies.
\end{abstract}

Keywords: talent; management; size of the company; process; performance

\section{Introduction}

The business environment nowadays is characterized by rapid technological, social, and economic changes, globalization, and mass customization of both production and consumption, which has led to hypercompetitive conditions in the market and competitive advantages have become temporary (Wee and Taylor 2018; D'Aveni et al. 2010; Oreg et al. 2018). In business, there are many challenges. Successful companies are very flexible in their reactions to external changes. They could respond very quickly, learn from the market, adapt a new culture, and implement changes to transform products and services according to external opportunities or threats (Braunscheidel and Suresh 2009; Sherehiy et al. 2007; Ahammad et al. 2020). Usually, these changes are connected with high tech development, implementing new apps, and robotics. However, several surveys emphasized the role of human power as the key element in successful changes (Zheltoukhova 2014). A focus on HR can strengthen positive effects in changes through innovations that are difficult to imitate for competitors (Zhou and Wu 2010). Almost all managers are focused on results, but only some of them respect the importance of human power in this process. People are movers of changes and bring added value to the organization. Thus, focus on human capital has become a strategic question in management systems.

Investing in people is the first and key element in a strategy of sustainability that involves the leveraging of talent as a key factor to human capital development (Rudito 2015). Organizations with high quality potential and talented people have a higher competitive ability in the future and talented 
employees have to perform an important role in the process of meeting strategic objectives with their rare knowledge and skills (Morris et al. 2016). Creating talent pipelines became one of the most important challenges in management (Cascio and Boudreau 2016) and talent management plays an important role in strategic renewal (Järvi and Khoreva 2020). Talent management has become a key strategic issue for leaders in companies (Krishnan and Scullion 2017).

How to define a talent? That is the question for many academics and managers as well. The term talent refers to a specific important skill and ability of humans, but also as a key person in the organization. This paper is oriented on persons who are talented and bring added value. Thus we use the term talent for key person with above normal skills and abilities in some areas (Silzer and Dowell 2009). Talents are individuals who demonstrate high potential and performance. Nowadays, in big competition environments, there is a need to manage these people and talent management has become one of the big challenges for HR managers. Some authors consider talent management as an integrated set of HR practices or functions, such as recruitment, selection, development, and performance appraisal, aimed at increasing the capacity of an organization (Fegley 2006; Mercer 2005; McGuire et al. 2010). Talent management is about talented individuals who are valuable and unique and can make valuable contributions to meet objectives and increase the capital of the owners (Collings and Mellahi 2009; Meyers and Woerkom 2014). Talented employees are valuable, rare, nonsubstitutable strategic assets for implementation of the strategies that can create value (Sparrow and Makram 2015). Nowadays, still more definitions about global talent management (GTM) can be found. Some authors (Collings et al. 2019) define GTM as the development of a talent pool of high-potential and high-performing incumbents who reflect the global scope of the company.

Talent management is perceived as a comprehensive guide to using strategic methods in HR to increase performance (Hunt 2014). Bethke-Langenegger et al. (2011) confirmed the fact that the talent management focusing on retaining and developing talents has a statistically significant positive impact on human resource outcomes such as job satisfaction, motivation, commitment, and trust in leaders. Harvey et al. (2002) explored the determinants of performance. They found talent as one important factor identified with high achievement. A talent management system positively influences a firm's ability to exploit knowledge and has an indirect positive effect on firm performance through its absorptive capacity (Latukha and Veselova 2019). Talent management is the way to increase the quality of human resources in each company, regardless of the size of the company. Talent management should be defined as a systematic and dynamic process of discovering, developing, and sustaining talent (Egerová et al. 2015). To manage the talent, a first step is to identify key positions in the organization (Collings et al. 2019). Recruitment activities represent initial efforts to attract highly qualified talents in the firm. It is one, and possibly the most important, step to acquire talents for achieving competitive advantage (Banks et al. 2019). Global talents are needed to create value. Identification of talents as another step in the talent management process has a limited impact on employee attitudes (Björkman et al. 2013). Talent development significantly influences organizational results, as shown in the results of the research, and there is positive connection between talent development efforts and performance of the firm (Latukha 2018). Careful deployment of talent management in the process of business strategy implementation may bring high economic value (Järvi and Khoreva 2020).

In current conditions, in an era of globalization, human capital plays a competitive advantage more and more. Talent management can be named as a strategic plan for organizations to improve their performance (Alruwaili 2018). Moreover, talent management practices with a strong focus on corporate strategy have a statistically higher significant impact on organizational outcomes, such as company attractiveness, the achievement of business goals, customer satisfaction, and, above all, corporate profit, more so than any other areas that talent management focuses upon. Size of the enterprise as an important factor influencing human resources management has been investigated in more scientific papers (Březinová and Vrchota 2016; Collings and Mellahi 2009). However, to the best of our knowledge, none of the studies have explored the relationship between talent management and 
the size of the company, because the majority of the results in the research field are connected with large multinational enterprises (Morley et al. 2015; Festing et al. 2013; Stahl et al. 2012; Vaiman et al. 2012; Iles et al. 2010) There are only a few articles that deal with talent management in a theoretical way in small and medium-sized companies (Krishnan and Scullion 2017; Festing et al. 2013). However, we think that talent plays an important role also in small and medium-sized companies because they make important contributions to the global economy (Festing 2007; OECD 2015) and HR practices generally are recognized as a key factor to contribute success in SME companies (Carlson et al. 2006; Heneman et al. 2000). Even we consider that some important steps in the talent management process should be on a better level in these companies compared to large ones. We reflect on the challenges in articles by Collings et al. (2019), Scullion et al. (2016), Krishnan and Scullion (2017), where the necessity of research in the area of talent management in SME companies is highlighted.

\section{Materials and Methods}

Research design, data obtained, and their structure in the research and methods used in this paper are described in this part. The aim of the paper was to identify if the size of the company is a significant factor influencing the talent management process in the entities running businesses in Slovakia. We obtained data from 379 companies operating in the different sectors of the economy. In the research sample (see Table 1), there were 181 (47.7\%) small, 113 (29.9\%) medium-sized, and 85 (22.4\%) large companies included in the research.

Table 1. Research sample according to size of the company.

\begin{tabular}{ccc}
\hline Size of the Company & Frequency & \% \\
\hline small company (10-49 employees) & 181 & 47.5 \\
middle-sized company (50-249 employees) & 113 & 29.7 \\
large company (250 and more employees) & 85 & 22.3 \\
Total & 379 & 99.5 \\
\hline Missing & 2 & 0.5 \\
Total & 381 & 100.0 \\
\hline
\end{tabular}

Selective survey was used as a method for data collection. A scaled questionnaire was used as a tool of collection data. This questionnaire was set up with the consortium of scientific researchers and modified for our research conditions (Egerová et al. 2015). It contained 41 items directly aimed to the talent management process, including HR strategy, identification, assessment, development, and retaining.

Here is the list of searched items:

Talent management is essential (I1). Talent management is an important part of our company's mission (I2). Top management worked out a joint attitude towards talent management (I3). We have a clearly defined human resources management strategy (I4). We have a clearly defined talent management strategy (I5). Talent management strategy is connected with strategic goals of our organization (I6). We are currently modifying the list of key talents indispensable in our company (I7). We search for talent in every single person that has just been employed (I8). Formulated talent management strategy is not difficult to realize in our company (I9). All positions in our company have been divided into key and peripheral positions (I10). Our workers' competences are adapted to their position requirements (I11). We are currently identifying talents among all the workers employed in our company (I12). We are currently identifying positions we need to recruit candidates for from the external environment (I13). We apply a plan of attracting talents from the external environment (I14). Our worker recruitment system makes it possible to acquire people of the highest development potential (I15). We know quite a lot about talents our employees have (I16). Talented people are willing to get employed by our company (I17). We know what talents we are going to need in the future (I18). We know how many talented people we are going to need in the future (I19). We perform some special 
activities designed to attract talents (I20). We systematically assess our workers' performance (I21). We promote our workers on the basis of objective criteria (I22). We draw conclusions from the workers' performance assessment (I23). Talent management is linked to the workers' reward system (I24). Talented people's assessment is performed on the basis of specially designed criteria (I25). The results of workers' performance assessment are used to formulate talent development plan (I26). We have clearly defined criteria of workers' performance assessment (I27). We use a wide range of forms and methods of our workers' competences development (I28). In the recruitment process we take into consideration some above average competences of potential workers (I29). We have well-formulated career paths of talented workers (I30). We develop talents thanks to the plans we implemented (I31). In most cases the positions where our employees work makes it possible to develop their talents (I32). We have enough time to develop our workers' talents (I33). We do have sufficient financial resources to support talent development (I34). We successfully retain talented people (I35). Talented people have financial requirements that we can meet (I36). We have a clear system of motivating workers (I37). We encounter problems as far as the communication with talented people is concerned (I38). We manage to retain talented workers by supporting them in their self-improvement process (I39). Talented people leave our company in search for new challenges (I40). We support talented people in a special way (I41). In Table 2 we can see variables operationalization.

Table 2. Variables operationalization in the questionnaire.

\begin{tabular}{|c|c|c|}
\hline Variables & Operationalization & Measurement \\
\hline Size of the company & $\begin{array}{l}\text { How many employees work in } \\
\text { your company? }\end{array}$ & $\begin{array}{l}\text { 1-less than } 50 ; 2-50-249 ; \\
3-250 \text { and more }\end{array}$ \\
\hline Strategy & Items 1-9 & $\begin{array}{l}\text { Likert scale 1-5: 1-totally } \\
\text { disagree, 3-neutral attitude; } \\
\text { 5-totally agree }\end{array}$ \\
\hline Talent identification & Items $10-20$ & $\begin{array}{l}\text { Likert scale 1-5: 1-totally } \\
\text { disagree, 3-neutral attitude; } \\
\text { 5-totally agree }\end{array}$ \\
\hline Assessment of talents & Items $21-27$ & $\begin{array}{l}\text { Likert scale 1-5: 1-totally } \\
\text { disagree, 3-neutral attitude; } \\
\text { 5-totally agree }\end{array}$ \\
\hline Talent development & Items $28-34$ & $\begin{array}{c}\text { Likert scale 1-5: } 1 \text {-totally } \\
\text { disagree, } 3 \text { - neutral attitude; } 5 \text { - } \\
\text { totally agree }\end{array}$ \\
\hline Retaining of talents & Items $35-41$ & $\begin{array}{c}\text { Likert scale 1-5: 1-totally } \\
\text { disagree, 3-neutral attitude; } 5 \\
\text { — totally agree }\end{array}$ \\
\hline
\end{tabular}

The items of the questionnaire were scaled according to Likert from 1 to 5 , where 1 means absolute disagreement of the respondent, 5 means absolute consensus, and 0 expressed irresolute attitude of the respondent. We added also position 0 , which enabled the respondent not to comment on a given item. The questionnaire was distributed online through Google documents system. We verified reliability of the questionnaire by means of Cronbach's alpha. The evaluation of scales was based on examining the correlations between the individual items or measurements in relation to the variability of the items. The value of Cronbach's alpha higher than 0.7 shows sufficient scale consistence. Cronbach's alpha reached level 0.864 for these items of the questionnaire. In Table 3 we can see results reliability verification. 
Table 3. Reliability verification of the questionnaire.

\begin{tabular}{ccccccc}
\hline $\begin{array}{c}\text { Number of } \\
\text { Items }\end{array}$ & $\begin{array}{c}\text { Valid } \\
\text { Instances }\end{array}$ & $\begin{array}{c}\text { with } \\
\text { Missing } \\
\text { Items }\end{array}$ & $\begin{array}{c}\text { Standard } \\
\text { Deviation }\end{array}$ & $\begin{array}{c}\text { Cronbach's } \\
\text { Alpha }\end{array}$ & $\begin{array}{c}\text { Standardized } \\
\text { Alpha } \\
\text { Coefficient }\end{array}$ & $\begin{array}{c}\text { Average } \\
\text { Correlation } \\
\text { between Items }\end{array}$ \\
\hline 41 & 156 & 225 & 17.841 & 0.864 & 0.874 & 0.154 \\
\hline
\end{tabular}

ANOVA as a statistical method was used to verify the existence of significant differences between the individual groups of respondents from small, medium-sized, and large companies. The aim of the test was to find whether the differences of the medians found in the sample of the individual groups were statistically significant (there is a relationship between the variables) or whether these were coincidental (there is no relationship between the variables) (Munk et al. 2010). We tested it on the $5 \%$ level of significance. If the $p$-value is lower than 0.05 , a statistically significant difference exists in the tested group.

\section{Results}

In our research, we examined what factors influence the process of talent management. We tested ownership, economic results, foreign capital, and existence of an HR department as the important factors of talent management in companies in Slovakia. The size of the company was recognized as the most significant factor. In Table 4, we can see the average score in all phases of the talent management process according to size factor. When we compare small, medium, and large companies, we recognized that the talent management process generally was on a higher level in large companies in almost each phase. Except retaining, where small companies were more successful compared to medium-sized and large companies. That was the reason why we searched differences in each phase in more detail.

Table 4. Average score of talent management level in the phases of talent management.

\begin{tabular}{cccccc}
\hline Size of the Company & Strategy & Identification & Assessment & Development & Retaining \\
\hline Small & 3.11 & 3.17 & 3.20 & 2.86 & 3.07 \\
Medium & 3.26 & 3.31 & 3.42 & 3.03 & 2.96 \\
Large & 3.42 & 3.44 & 3.56 & 3.11 & 2.96 \\
\hline
\end{tabular}

\subsection{HR Strategy and Talents}

Strategy plays important role for each company. A well-formulated and implemented strategy leads to better results. There is a necessity of strategy consistency on each level. HR strategy usually belongs to functional strategies, which are on the bottom level in companies. However, its importance is very high. Ahammad et al. (2020) and Collings and Mellahi (2009) suggested to implement talent management as part of the HR strategy. It could bring many benefits connected with the creation of economic values (Järvi and Khoreva 2020).

In the Table 5, the average scores of items in the area of HR strategy according to size of the company are displayed. In each item, large companies reached better results compared to SMEs. It is a standard result because strategic orientation is much more significant in large companies. It is a well-known fact that large companies have greater motivation to think strategically and prepare strategic changes. We identified three significant differences according to size of the company in answers of respondents about the first phase of talent management-HR strategy. We used ANOVA and all of these differences are highlighted in Table 6 (items I4, I5, and I7). These items were investigated via post hoc tests (Table 6) to identify between which groups of respondents the differences originated. 
Table 5. Average scores of items in the phase of strategy according to size of the company.

\begin{tabular}{ccccccccccc}
\hline Size of the Company & Statistics & I1 & I2 & I3 & I4 & I5 & I6 & I7 & I8 & I9 \\
\hline \multirow{3}{*}{ Small } & Valid & 176 & 178 & 168 & 178 & 171 & 177 & 173 & 178 & 172 \\
\cline { 2 - 11 } & Mean & 3.61 & 3.39 & 3.36 & 3.31 & 2.74 & 2.93 & 2.65 & 3.55 & 2.45 \\
\cline { 2 - 10 } & Std. Dev. & 1.03 & 1.05 & 1.06 & 1.14 & 1.05 & 1.10 & 1.13 & 1.21 & 0.99 \\
\hline \multirow{3}{*}{ Middle } & Valid & 109 & 110 & 105 & 109 & 109 & 104 & 98 & 109 & 104 \\
\cline { 2 - 10 } & Mean & 3.68 & 3.41 & 3.42 & 3.68 & 3.03 & 3.10 & 3.06 & 3.54 & 2.43 \\
\cline { 2 - 10 } & Std. Dev. & 1.03 & 1.08 & 1.14 & 1.04 & 1.01 & 1.10 & 1.09 & 1.09 & 0.94 \\
\hline \multirow{3}{*}{ Large } & Valid & 85 & 84 & 82 & 84 & 82 & 79 & 73 & 83 & 83 \\
\cline { 2 - 10 } & Mean & 3.73 & 3.52 & 3.59 & 4.05 & 3.33 & 3.22 & 3.07 & 3.58 & 2.69 \\
\cline { 2 - 10 } & Std. Dev. & 1.15 & 1.11 & 1.13 & 0.96 & 1.24 & 1.19 & 1.19 & 1.23 & 1.04 \\
\hline
\end{tabular}

Table 6. (A) Significant differences in HR strategy according to size of the company (ANOVA) and Post hoc tests for significant differences in HR strategy (Tukey HSD). (B) Post hoc tests for significant differences in HR strategy (Tukey HSD).

\begin{tabular}{cccccccccc}
\hline Item & I1 & I2 & I3 & I4 & I5 & I6 & I7 & I8 & I9 \\
\hline Mean Square & 0.413 & 0.548 & 1.372 & 15.975 & 10.097 & 2.404 & 7.270 & 0.034 & 1.869 \\
\hline F & 0.370 & 0.475 & 1.133 & 13.867 & 8.586 & 1.918 & 5.666 & 0.025 & 1.923 \\
\hline$p$ value & 0.691 & 0.622 & 0.323 & 0.000 & 0.000 & 0.148 & 0.004 & 0.976 & 0.148 \\
\hline
\end{tabular}

(B)

\begin{tabular}{ccccc}
\hline \multicolumn{2}{c}{ Size of the Company } & Sig. I4 & Sig. I5 & Sig. I7 \\
\hline small & medium & 0.015 & 0.075 & 0.013 \\
\hline small & large & 0.000 & 0.000 & 0.024 \\
\hline medium & large & 0.048 & 0.139 & 0.999 \\
\hline
\end{tabular}

Let us see these differences in more detail. In item I4, we investigated whether HR strategy is clearly defined. We found that differences exist among all groups simultaneously. We concluded that HR strategy is on a higher level in large companies compared to small and medium-sized companies. The reasoning can be explained, thereby, that in smaller companies there are no people delegated to create such a strategy and HR strategy does not exist. In small companies, people are multifunctional and perform more activities and a specialist for HR who can create and then meet HR strategy does not exist. For the same reason, talent definition and talent strategy were missing in these companies, which should be a natural part of HR strategy. This difference was identified in item I5 and exists only between small and large companies. Another difference was identified in item I7. This item was focused on the fact of whether management of the company modifies the list of talents needed in the future. Differences could be seen only between small companies on one side and medium or large on the other side. We concluded that medium and large companies are better in the process of modifying of talents needed. They scan the external environment on a higher level and results are implemented into HR strategy. This fact influences the list of talents needed for the future existence of the company.

\subsection{Identification and Recruitment of Talents}

Identification and recruitment of talented people who can increase added value is a very difficult but important process. This should be realized inside and also outside of the company; thus the sources should be different. In the business sphere, usually talents are identified inside and if required talents are not found there this process continues outside of the company. Al Ariss et al. (2014) told us that the successful process of talent management starts with identification of key positions that are more important for the company and can create the organization's sustainable competitive advantage. Therefore, it is necessary to create and implement HR plans because the wrong man in a 
key position could bring disastrous consequences. This plan mirrors the need for employees to respect the requirements for a working position. To recruit key employees, it is useful to perform some special activities such as an analysis of working positions, recruiting and staffing, selection, talent review, and succession planning.

Table 7 shows average scores of items in the process of talent identification according to size of the company. Generally, large companies reached higher scores in the researched items of the questionnaire and we can conclude that they have a bigger tendency to agree with these items, thus we consider that talent identification and recruitment are there on a better level. As we can see only in items I11, I12, and I16, SMEs reached better scores compared to large companies. However, these differences were not statistically significant. We identified five significant differences (in favor of large companies) in this phase of talent management (I13, I14, I18, I19, I20-highlighted in Table 8). These items were investigated via post hoc tests (Table 8 ) to identify between which groups of respondents the differences originated.

Table 7. Average scores of items in the phase of talent identification according to size of the company.

\begin{tabular}{ccccccccccccc}
\hline $\begin{array}{c}\text { Size of the } \\
\text { Company }\end{array}$ & Statistics & $\mathbf{I 1 0}$ & $\mathbf{I 1 1}$ & $\mathbf{I 1 2}$ & $\mathbf{I 1 3}$ & $\mathbf{I 1 4}$ & $\mathbf{I 1 5}$ & $\mathbf{I 1 6}$ & $\mathbf{I 1 7}$ & $\mathbf{I 1 8}$ & $\mathbf{I 1 9}$ & $\mathbf{I 2 0}$ \\
\hline \multirow{4}{*}{ small } & Valid & 174 & 177 & 169 & 172 & 168 & 174 & 178 & 173 & 174 & 171 & 164 \\
& Mean & 3.52 & 3.95 & 3.15 & 2.85 & 2.92 & 3.38 & 3.11 & 3.40 & 3.17 & 2.84 & 2.52 \\
& Std. Dev. & 1.21 & 1.13 & 1.14 & 1.17 & 1.25 & 1.20 & 1.14 & 1.04 & 1.21 & 1.14 & 1.10 \\
\hline \multirow{4}{*}{ middle } & Valid & 112 & 112 & 107 & 106 & 101 & 109 & 108 & 108 & 104 & 101 & 106 \\
& Mean & 3.54 & 4.13 & 3.45 & 3.07 & 3.27 & 3.57 & 3.04 & 3.42 & 3.39 & 2.89 & 2.69 \\
& Std. Dev. & 1.14 & 0.88 & 1.04 & 1.11 & 1.10 & 1.10 & 1.13 & 0.97 & 1.13 & 1.03 & 1.11 \\
\hline \multirow{4}{*}{ large } & Valid & 83 & 83 & 79 & 80 & 79 & 84 & 82 & 83 & 80 & 78 & 78 \\
& Mean & 3.61 & 4.08 & 3.37 & 3.36 & 3.44 & 3.58 & 3.00 & 3.41 & 3.65 & 3.24 & 3.09 \\
& Std. Dev. & 1.21 & 0.93 & 1.06 & 1.03 & 1.06 & 1.10 & 1.02 & 0.84 & 0.96 & 1.08 & 1.15 \\
\hline
\end{tabular}

Table 8. (A) Significant differences in talent identification according to size of the company (ANOVA) and (B) Post hoc tests for significant differences in talent identification (Tukey HSD).

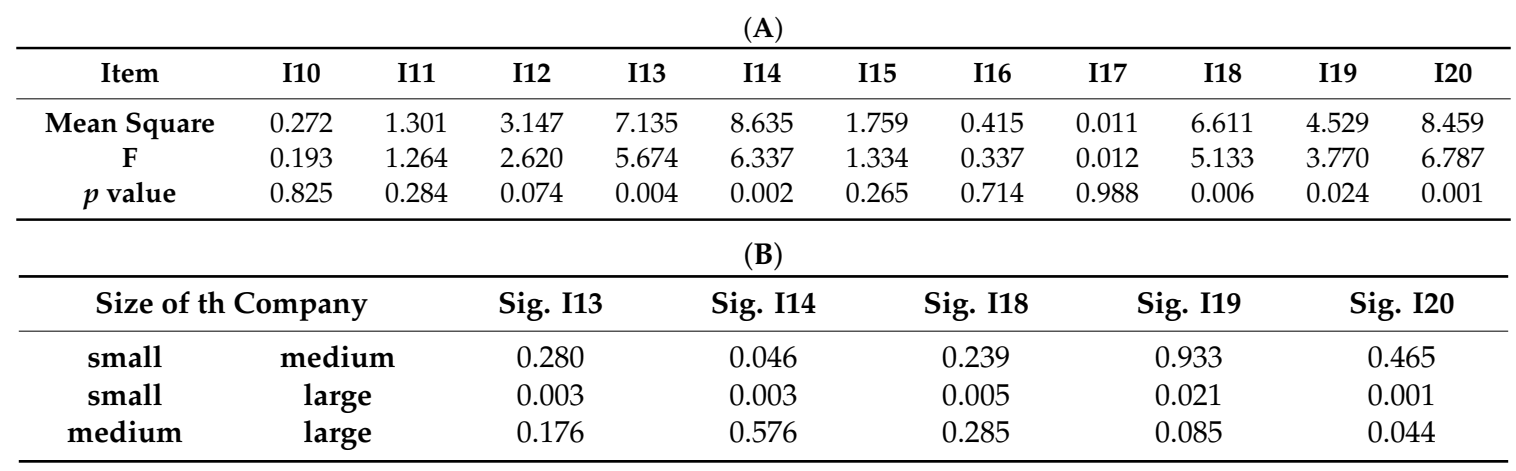

We can see differences resulting from item I13, where respondents from large companies showed differences in the process of positions analysis where external candidates will be required. The average score was higher in large companies compared to small ones. This process is on a better level in large companies due to higher strategic orientation for external changes. This is strongly connected with item I14 where differences were shown in plans of talent recruiting from the external environment. We considered that plans in large companies are clearly defined compared to small companies. Strategic orientation on external environment occurs in small companies only rarely. Talent identification for the future from the aspect of quality and quantity (as shown in items I18, I19) was better in large companies compared to small. Large companies also realized more special activities focused on talent recruiting (I20). 


\subsection{Talent Assessment}

Generally, the main objective of employee assessment is to improve business processes. In the process of talent assessment, employees should be systematically evaluated from the aspect of performance but also from the perspective of growth and development (Davis et al. 2016). This kind of evaluation system can bring valuable information for further development of individuals, but also for development of whole organization. Therefore, the assessment system should be based on unbiased and measured criteria, those that can meet the function of motivation to increase the performance. A properly defined system mirrors the priorities of the company and can be used for a remuneration system. Results of assessment must be implemented into selection to talent pool. Talented individuals should have special objectives and criteria for their own evaluation.

Items I21 to I27 in the research were oriented to the talent assessment process. From the average score (see Table 9), we concluded that in six of seven cases the best results were in large companies, and therefore we can say that talent assessment is on a higher level in large companies compared to small and medium-sized companies. In four items, significant differences were found (items I21, I25, I26, I27-highlighted in Table 10). These items were investigated via post hoc tests (Table 10) to identify between which groups of respondents the differences originated.

Table 9. Average scores of items in the phase of talent assessment according to size of the company.

\begin{tabular}{ccccccccc}
\hline Size of the Company & Statistics & I21 & I22 & I23 & I24 & I25 & I26 & I27 \\
\hline \multirow{4}{*}{ small } & Valid & 179 & 169 & 167 & 171 & 170 & 173 & 171 \\
& Mean & 3.36 & 3.41 & 3.43 & 2.96 & 2.77 & 3.23 & 3.25 \\
& Std. Dev. & 1.20 & 1.17 & 1.11 & 1.29 & 1.14 & 1.14 & 1.30 \\
\hline \multirow{4}{*}{ middle } & Valid & 110 & 112 & 106 & 104 & 105 & 110 & 107 \\
& Mean & 3.73 & 3.46 & 3.42 & 3.23 & 2.98 & 3.48 & 3.61 \\
& Std. Dev. & 1.09 & 1.19 & 1.17 & 1.11 & 1.13 & 1.12 & 1.18 \\
\hline \multirow{3}{*}{ large } & Valid & 84 & 84 & 80 & 80 & 73 & 82 & 79 \\
& Mean & 4.08 & 3.55 & 3.46 & 3.30 & 3.18 & 3.66 & 3.68 \\
& Std. Dev. & 0.97 & 1.11 & 1.20 & 1.16 & 1.13 & 0.98 & 1.14 \\
\hline
\end{tabular}

Table 10. (A) Significant differences in talent assessment according to size of the company (ANOVA) and (B) Post hoc tests for significant differences in talent assessment (Tukey HSD).

(A)

\begin{tabular}{cccccccc}
\hline Item & I21 & I22 & I23 & I24 & I25 & I26 & I27 \\
\hline Mean Square & 15.525 & 0.548 & 0.052 & 4.145 & 4.524 & 5.745 & 7.053 \\
F & 12.389 & 0.406 & 0.040 & 2.828 & 3.509 & 4.747 & 4.673 \\
$\boldsymbol{p}$ value & 0.000 & 0.667 & 0.961 & 0.060 & 0.031 & 0.009 & 0.010 \\
\hline
\end{tabular}

(B)

\begin{tabular}{cccccc}
\hline \multicolumn{2}{c}{ Size of the Company } & Sig. I21 & Sig. I25 & Sig. I26 & Sig. I27 \\
\hline small & medium & 0.021 & 0.296 & 0.137 & 0.046 \\
small & large & 0.000 & 0.029 & 0.010 & 0.025 \\
medium & large & 0.073 & 0.490 & 0.514 & 0.908 \\
\hline
\end{tabular}

These differences show us that employee assessment is less systematic (I21) in small companies compared to medium and large ones. Usually, there is no will and time to provide any sophisticated assessment of all employees. Systematic assessment used mostly in larger companies includes clearly defined specific criteria for the evaluation of talented individuals compared to all other employees (I25). Talented individuals are usually assessed according to performance and value added for the company. The assessment of talents according to innovation potential, which is provided in large companies, is also very interesting. In large and medium-sized companies, the criteria for employee assessment 
are clearly defined and people know these criteria from the beginning (I27) and what is very important is that the results of this evaluation are used more often in plans for further development in large companies compared to small ones (I26).

\subsection{Talent Development}

When a company would like to exist for a longer time then it must invest money for development. Not only into tangible assets but also to people. They are movers in each company to increase the value of the business. To meet this idea, employees need to improve their skills, knowledge, and experience constantly. Only this kind of employee should represent flexible human power because requirements for each working position are still higher considering new methods and technological developments. That is the reason why new methods of human resources development focused on talents are required in management systems. Many successful companies used systems of carrier plans for talents to secure improvement of the organization. For systematic talent development, sufficient money, willingness, and time are needed. Talented people need and want to take charge of their own development with the support from the management (Barlow 2006).

Items I28 to I34 of the research were focused on talent development. Large companies reached the highest score in four items, medium-sized companies in two items, and small companies in one item (see Table 11). An interesting fact is that representatives in small companies took more time to develop employee's talents (I33), but this differences was not significant. We tested if some statistically significant differences exist among responses of representatives from each group of respondents. We identified four significant differences (items I28, I29, I31, I34-highlighted in Table 12). These items were investigated via post hoc tests (Table 12) to identify between which groups of respondents the differences originated.

Table 11. Average scores of items in the phase of talent development according to size of the company.

\begin{tabular}{ccccccccc}
\hline Size of the Company & Statistics & $\mathbf{I 2 8}$ & $\mathbf{I 2 9}$ & $\mathbf{I 3 0}$ & $\mathbf{I 3 1}$ & $\mathbf{I 3 2}$ & $\mathbf{I 3 3}$ & $\mathbf{I 3 4}$ \\
\hline \multirow{4}{*}{ small } & Valid & 165 & 161 & 166 & 167 & 173 & 171 & 171 \\
& Mean & 2.67 & 3.37 & 2.72 & 2.57 & 3.00 & 3.07 & 2.64 \\
& Std. Dev. & 1.03 & 1.21 & 1.09 & 1.01 & 1.34 & 1.26 & 1.23 \\
\hline \multirow{3}{*}{ middle } & Valid & 107 & 109 & 102 & 104 & 112 & 105 & 106 \\
& Mean & 2.90 & 3.87 & 2.81 & 2.77 & 3.11 & 3.01 & 2.73 \\
& Std. Dev. & 1.09 & 1.09 & 1.02 & 1.04 & 1.28 & 1.24 & 1.14 \\
\hline \multirow{3}{*}{ large } & Valid & 83 & 78 & 83 & 82 & 80 & 83 & 82 \\
& Mean & 3.34 & 3.63 & 3.01 & 3.05 & 2.59 & 3.01 & 3.11 \\
& Std. Dev. & 1.05 & 1.19 & 1.19 & 1.05 & 1.27 & 1.30 & 1.33 \\
\hline
\end{tabular}

Table 12. (A) Significant differences in talent development according to size of the company (ANOVA) and (B) Post hoc tests for significant differences in talent development (Tukey HSD).

(A)

\begin{tabular}{cccccccc}
\hline Item & I28 & I29 & I30 & I31 & I32 & I33 & I34 \\
\hline Mean Square & 12.197 & 8.177 & 2.411 & 6.230 & 0.483 & 0.159 & 6.336 \\
F & 11.044 & 5.976 & 2.006 & 5.876 & 0.283 & 0.099 & 4.203 \\
$\boldsymbol{p}$ value & 0.000 & 0.003 & 0.136 & 0.003 & 0.753 & 0.905 & 0.016 \\
\hline
\end{tabular}

(B)

\begin{tabular}{cccccc}
\hline Size of the Company & Sig. I28 & Sig. I29 & Sig. I31 & Sig. I34 \\
\hline small & medium & 0.199 & 0.002 & 0.287 & 0.828 \\
small & large & 0.000 & 0.254 & 0.002 & 0.012 \\
medium & large & 0.012 & 0.341 & 0.159 & 0.087 \\
\hline
\end{tabular}


The difference in item I28 showed us that in large companies compared to others there are more special methods for people development used in their system. In large companies there are more possibilities, and also the experience of managers, to use adequate methods for developments of competencies, compared to small and medium-sized companies. A difference in item 29 also exists. It showed that exceptional skills of talents are taken into account in the process of selection to the talent pool and further carrier growth in medium-sized companies compared to small ones. The difference in item I31 shows better levels of human resources planning in large companies compared to small ones, while talents in large companies are developed according to defined plans. Important tasks in talent development effect the financial situation but also vision of the company. That is the reason why large companies are more successful in this process compared to small (I34).

\subsection{Talent Retention}

Fluctuation decreases the quality of labor power and increases costs for personal activities. Therefore, retention of key talented individuals plays an important role on the way to success. Thus, an accurate motivation system, remuneration, and communication is needed in this process. Kontoghiorghes and Frangou (2009) added employee autonomy, risk taking, tolerance of mistakes, open communications, and education as the factors of an employee's confidence that should help to retain talents. Personal policy usually represented with care for employees beyond the scope of the law is used as a popular tool. This tool must be connected also with the possibility of self-development and self-realization. These are the ways to retain talented individuals and not to lose them due to external challenges.

Item I35-I41 were focused on retention of talents in the companies. Very interesting is the fact that even in six items out of seven, small companies dominated and reached the highest average score compared to medium-sized and large (see Table 13) companies. That indicates a higher ability to retain talents in small companies. According these items, representatives showed the ability to meet financial requirements, and clear motivation systems are adopted in small companies. Also, other factors of talent retention, such as communication about problems, support of talent self-improvement, and searching for new challenges, are on a higher level in small companies. In this phase, only one statistically significant difference was found. It was in item I40, as highlighted in Table 14. This difference occurred between small and medium-sized companies. These items were investigated via post hoc tests (Table 14) to identify between which groups of respondents the differences originated.

Table 13. Average scores of items in the phase of retaining of talents according to size of the company.

\begin{tabular}{ccccccccc}
\hline Size of the Company & Statistics & I35 & I36 & I37 & I38 & I39 & I40 & I41 \\
\hline \multirow{3}{*}{ small } & Valid & 170 & 175 & 173 & 172 & 168 & 169 & 167 \\
& Mean & 3.24 & 2.92 & 3.09 & 3.44 & 3.20 & 2.91 & 2.68 \\
& Std. Dev. & 1.12 & 1.13 & 1.22 & 1.11 & 1.08 & 1.28 & 1.09 \\
\hline \multirow{3}{*}{ middle } & Valid & 109 & 104 & 111 & 106 & 105 & 106 & 101 \\
& Mean & 3.04 & 2.76 & 3.06 & 3.42 & 3.20 & 2.47 & 2.74 \\
& Std. Dev. & 0.92 & 1.00 & 1.19 & 1.04 & 1.11 & 1.10 & 1.26 \\
\hline \multirow{3}{*}{ large } & Valid & 83 & 80 & 82 & 79 & 81 & 84 & 76 \\
& Mean & 2.99 & 2.75 & 2.96 & 3.32 & 2.93 & 2.68 & 3.08 \\
& Std. Dev. & 0.99 & 1.11 & 1.22 & 1.16 & 1.18 & 1.29 & 1.34 \\
\hline
\end{tabular}


Table 14. (A) Significant differences in retention of talents according to size of the company (ANOVA) and (B) Post hoc tests for significant differences in retention of talents (Tukey HSD).

(A)

\begin{tabular}{cccccccc}
\hline Item & I35 & I36 & I37 & I38 & I39 & I40 & I41 \\
\hline Mean Square & 2.231 & 1.217 & 0.469 & 0.397 & 2.250 & 6.421 & 4.284 \\
F & 2.078 & 1.024 & 0.319 & 0.328 & 1.810 & 4.246 & 2.967 \\
$p$ value & 0.127 & 0.360 & 0.727 & 0.721 & 0.165 & 0.015 & 0.053 \\
\hline
\end{tabular}

(B)

\begin{tabular}{ccc}
\hline & Size of the Company & Sig. I40 \\
\hline small & medium & 0.012 \\
small & large & 0.333 \\
medium & large & 0.483 \\
\hline
\end{tabular}

We can consider that small companies can retain talented employees due to better work climate, atmosphere, and stronger connections among owners, managers, and employees. Many times these relationships look familiar. Then, people do not want to escape and leave this organization due to some external opportunities from other competitors (I40).

\section{Conclusions}

Talent management represents a modern approach to human resources in companies. Main phases of the talent management process, such as a strategy for talent identification, assessment, development, and retaining, are influenced by many factors. In previous research we already searched ownership, economic results, existence of HR department, and foreign capital as important factors influencing level of talent management in organizations. However, according to our research, size of the company is one of the strongest factors. As stated in our research, large companies realize talent management on higher level in four out of five phases. The main significant differences among small, medium, and large companies are connected with higher strategic orientation for talents, modification of the list of talents for the future, plans for recruiting talented individuals, special activities in recruiting and development of talents, systematic assessment with special criteria, implementation to carrier plans, exceptional skills which are taken into account in the process of selection. However, a very interesting finding was that the process of retaining talents in small companies reached better results due to the better working climate, atmosphere, open communication, and familiar relationships. Although large companies have more possibilities to retain talented individuals, they usually leave the company due to other challenges and retention is not very successful.

In this article, we would like to express that size of the company is a very important factor that influences talent management in organizations. From the sample of 379 companies operating in the different sectors of the economy, we assumed that large companies would have better results. Our results confirmed that in a general sense. However, in the process of retention, small companies are more successful and it could be next topic for researchers to describe this anomaly in a deeper way. A limitation of this research consists of the focus on all main phases of talent management. However, the interpretation and findings, and the reasons why it is so, are based on interviews with a small number of HR managers. That is the proposal for following research-to find main reasons in each phase for better and deeper interpretation. 
Author Contributions: Conceptualization, R.S.; methodology, R.S. and D.L.; software, R.S.; validation, R.S., D.L., and J.K.; formal analysis, R.S.; investigation, R.S. and D.L.; resources, R.S. and J.K.; data curation, R.S. and D.L.; writing—original draft preparation, R.S.; writing—review and editing, D.L.; visualization, J.K.; supervision, R.S.; project administration, R.S.; funding acquisition, R.S. All authors have read and agreed to the published version of the manuscript.

Funding: This research was funded by the project VEGA “Integrated talent management model and its impact on economic results of enterprises" from The Ministry of Education, Science, Research, and Sport of the Slovak Republic. Project registration number VEGA 1/0543/17.

Conflicts of Interest: The authors declare no conflict of interest. The funders had no role in the design of the study; in the collection, analyses, or interpretation of data; in the writing of the manuscript, or in the decision to publish the results.

\section{References}

Ahammad, Mohammad F., Keith W. Glaister, and Emanuel Gomes. 2020. Strategic agility and human resource management. Human Resource Management Review 30. [CrossRef]

Alruwaili, Naif Fawzi. 2018. Talent Management and Talent Building in Upgrading Employee Performance. European Journal of Sustainable Development 7: 98. [CrossRef]

Al Ariss, Akram, Wayne F. Cascio, and Jaap Paauwe. 2014. Talent management: Current theories and future research directions. Journal of World Business 49: 173-79. [CrossRef]

Banks, George C., Haley M. Woznyj, Ryan S. Wesslen, Katherine A. Frear, Gregory Berka, Eric D. Heggestad, and Heather L. Gordon. 2019. Strategic recruitment across borders: An investigation of multinational enterprises. Journal of Management 45: 476-509. [CrossRef]

Barlow, Liz. 2006. Talent development: The new imperative? Development and Learning in Organizations: An International Journal. [CrossRef]

Bethke-Langenegger, Pamela, Philippe Mahler, and Bruno Staffelbach. 2011. Effectiveness of talent management strategies. European Journal of International Management 5: 524-39. [CrossRef]

Björkman, Ingmar, Mats Ehrnrooth, Kristiina Mäkelä, Adam Smale, and Jennie Sumelius. 2013. Talent or not? Employee reactions to talent identification. Human Resource Management 52: 195-214. [CrossRef]

Braunscheidel, Michael J., and Nallan C. Suresh. 2009. The organizational antecedents of a firm's supply chain agility for risk mitigation and response. Journal of operations Management 27: 119-40. [CrossRef]

Březinová, Monika, and Jaroslav Vrchota. 2016. Selected Processes in SMEs, Targeting to South Bohemia Region and Trade Sector. Acta Universitatis Agriculturae et Silviculturae Mendelianae Brunensis 64: 589-94. [CrossRef]

Carlson, Dawn S., Nancy Upton, and Samuel Seaman. 2006. The impact of human resource practices and compensation design on performance: An analysis of family-owned SMEs. Journal of Small Business Management 44: 531-43. [CrossRef]

Cascio, Wayne F., and John W. Boudreau. 2016. The search for global competence: From international HR to talent management. Journal of World Business 51: 103-14. [CrossRef]

Collings, David G., and Kamel Mellahi. 2009. Strategic talent management: A review and research agenda. Human Resource Management Review 19: 304-13. [CrossRef]

Collings, David G., Kamel Mellahi, and Wayne F. Cascio. 2019. Global talent management and performance in multinational enterprises: A multilevel perspective. Journal of Management 45: 540-66. [CrossRef]

D'Aveni, Richard A., Giovanni Battista Dagnino, and Ken G. Smith. 2010. The age of temporary advantage. Strategic Management Journal 31: 1371-85. [CrossRef]

Davis, Tony, Maggie Cutt, Neil Flynn, and Peter Mowl. 2016. Talent Assessment: A New Strategy for Talent Management. London: Routledge.

Egerová, Dana, Drahoslav Lančarič, Ludvík Eger, and Radovan Savov. 2015. Perspectives of talent management: Evidence from Czech and Slovak business organisations. Economics and Management. [CrossRef]

Fegley, Shawn. 2006. Talent Management Survey Report. Alexandria: Society for Human Resource Management (SHRM), 36p.

Festing, Marion. 2007. Globalisation of SMEs and implications for international human resource management research and practice. International Journal of Globalisation and Small Business 2: 5-18. [CrossRef] 
Festing, Marion, Lynn Schäfer, and Hugh Scullion. 2013. Talent management in medium-sized German companies: An explorative study and agenda for future research. The International Journal of Human Resource Management 24: 1872-93. [CrossRef]

Harvey, Janet, Andrew Pettigrew, and Ewan Ferlie. 2002. The determinants of research group performance: Towards mode 2? Journal of Management Studies 39: 747-74. [CrossRef]

Heneman, Robert L., Judith W. Tansky, and S. Michael Camp. 2000. Human resource management practices in small and medium-sized enterprises: Unanswered questions and future research perspectives. Entrepreneurship Theory and Practice 25: 11-26. [CrossRef]

Hunt, Steven T. 2014. Common Sense Talent Management: Using Strategic Human Resources to Improve Company Performance. Hoboken: John Wiley \& Sons.

Iles, Paul, Xin Chuai, and David Preece. 2010. Talent management and HRM in multinational companies in Beijing: Definitions, differences and drivers. Journal of World Business 45: 179-89. [CrossRef]

Järvi, Kati, and Violetta Khoreva. 2020. The role of talent management in strategic renewal. Employee Relations: The International Journal. [CrossRef]

Kontoghiorghes, Constantine, and Kalomyra Frangou. 2009. The association between talent retention, antecedent factors, and consequent organizational performance. SAM Advanced Management Journal 74: 29.

Krishnan, T. N., and Hugh Scullion. 2017. Talent management and dynamic view of talent in small and medium enterprises. Human Resource Management Review 27: 431-41. [CrossRef]

Latukha, Marina O. 2018. Talent development and a firm's performance: Evidence from Russian companies. Journal of General Management 43: 51-62. [CrossRef]

Latukha, Marina, and Anna Veselova. 2019. Talent management, absorptive capacity, and firm performance: Does it work in China and Russia? Human Resource Management 58: 503-519. [CrossRef]

McGuire, David, Mammed Bagher, Jim Stewart, and Victoria Harte. 2010. The implications of talent management for diversity training: An exploratory study. Journal of European Industrial Training. [CrossRef]

Mercer, S. R. 2005. Best-in-class leadership. Leadership Excellence 22: 17.

Meyers, Maria Christina, and Marianne Van Woerkom. 2014. The influence of underlying philosophies on talent management: Theory, implications for practice, and research agenda. Journal of World Business 49: 192-203. [CrossRef]

Morley, Michael J., Hugh Scullion, David G. Collings, and Randall S. Schuler. 2015. Talent management: A capital question. European Journal of International Management 9: 1-8. [CrossRef]

Morris, Shad, Scott Snell, and Ingmar Björkman. 2016. An architectural framework for global talent management. Journal of International Business Studies 47: 723-47. [CrossRef]

Munk, Michal, Jozef Kapusta, and Peter Švec. 2010. Data preprocessing evaluation for web log mining: Reconstruction of activities of a web visitor. Procedia Computer Science 1: 2273-80. [CrossRef]

OECD. 2015. Taxation of SMEs in OECD and G20 Countries. OECD Tax Policy Studies No. 23. Paris: OECD.

Oreg, Shaul, Jean M. Bartunek, Gayoung Lee, and Boram Do. 2018. An affect-based model of recipients' responses to organizational change events. Academy of Management Review 43: 65-86. [CrossRef]

Rudito, Priyantono. 2015. Leveraging Global Talent: Strategic Leverage to Achieve Excellent Business Performance. Advanced Science Letters 21: 1064-69. [CrossRef]

Scullion, Hugh, Vlad Vaiman, David G. Collings, and Marian Thunnissen. 2016. Talent management. Employee Relations. [CrossRef]

Sherehiy, Bohdana, Waldemar Karwowski, and John K. Layer. 2007. A review of enterprise agility: Concepts, frameworks, and attributes. International Journal of Industrial Ergonomics 37: 445-60. [CrossRef]

Silzer, Rob, and Ben E. Dowell, eds. 2009. Strategy-Driven Talent Management: A Leadership Imperative. Hoboken: John Wiley \& Sons.

Sparrow, Paul R., and Heba Makram. 2015. What is the value of talent management? Building value-driven processes within a talent management architecture. Human Resource Management Review 25: $249-63$. [CrossRef]

Stahl, Günter, Ingmar Björkman, Elaine Farndale, Shad S. Morris, Jaap Paauwe, Philip Stiles, Jonathan Trevor, and Patrick Wright. 2012. Six principles of effective global talent management. Sloan Management Review 53: 25-42. [CrossRef]

Vaiman, Vlad, Hugh Scullion, and David Collings. 2012. Talent management decision making. Management Decision. [CrossRef] 
Wee, Elijah X., and M. Susan Taylor. 2018. Attention to change: A multilevel theory on the process of emergent continuous organizational change. Journal of Applied Psychology 103: 1. [CrossRef]

Zheltoukhova, Ksenia. 2014. HR: Getting Smart about Agile Working. CIPD Research Paper. London: Chartered Institute of Personnel and Development.

Zhou, Kevin Zheng, and Fang Wu. 2010. Technological capability, strategic flexibility, and product innovation. Strategic Management Journal 31: 547-61. [CrossRef] 